\title{
Film formation by marine bacteria at a model fluid interface
}

\author{
Vera Žutić ${ }^{1, *}$, Nadica Ivošević ${ }^{1}$, Vesna Svetličić ${ }^{1}$, Richard A. Long ${ }^{2}$, Farooq Azam ${ }^{2}$ \\ ${ }^{1}$ Center for Marine and Environmental Research, Ruđer Bošković Institute, POB 1016, 10001 Zagreb, Croatia \\ ${ }^{2}$ Marine Biology Research Division, Scripps Institution of Oceanography, University of California San Diego, La Jolla, \\ California 92093-0202, USA
}

\begin{abstract}
We have characterized the nonspecific interactions in the initial attachment and film formation by marine bacteria at a dynamic fluid interface: seawater/dropping mercury electrode. Experimental evidence is presented that bacteria readily establish molecular contact with the metal substrate without mediation of a conditioning film. Prevalence of hydrophobic over electrostatic interactions and the possible importance of $\mathrm{Ca}^{2+}$ bridging could be inferred. The attachment of individual bacterial cells is faster than their transport from the aqueous medium, as is the case in the transport-controlled adsorption of biopolymers. The cell aggregates yield distinct electrical attachment signals, allowing a comparison between cell-cell and cell-substrate affinities. The cell-cell interactions, as well as the interaction of cell aggregates with negatively charged substrate, were greatly enhanced in seawater compared to pure $\mathrm{NaCl}$ solutions. The model experiments point out that marine bacteria should represent a significant component of the initial film formed at freshly exposed surfaces in seawater. This was found to hold for bacterial strains whether they were initially isolated as attached or as free-living.
\end{abstract}

KEY WORDS: Marine bacteria films - Bacterial attachment - Electrochemical detection of adhesion

\section{INTRODUCTION}

It has been generally accepted that the first step in the formation of a bacterial film on a clean surface is the adsorption of an organic layer onto the surface from the aqueous milieu. The adsorption of the organic layer, often referred to as a conditioning film, is fast (seconds) and it is often considered inevitable in the marine environment (Cooksey \& Wigglesworth-Cooksey 1995 and references therein). However, there is no conclusive evidence that microorganisms require a conditioned substratum to adsorb to a surface (Paul \& Jeffrey 1985, Characklis \& Marshall 1990, Samuelsson \& Kirchman 1990).

The importance of bacterial films in the strength of particle aggregates was indicated by Muschenheim et al. (1987) and Vaque et al. (1990). More recently, Johnson \& Asetzu-Scott (1995) performed direct measurements of the forces that hold surfaces in molecular contact in seawater; their results showed that the

•E-mail: zutic@rudjer.irb.hr formation of bacterial films caused a marked increase in the adhesion forces between glass spheres. Such adhesion studies were mostly designed to follow the net effects of a permanent adhesion process at a static interface (Cooksey \& Wigglesworth-Cooksey 1995).

Interfaces in the marine environment which exhibit a high tendency for accumulating bacteria are often fluid and flexible, such as air/water and gas bubbles (Blanchard 1983, Kjelleberg 1985), oil droplets, transparent organic particles (Alldredge et al. 1993, Long \& Azam 1996) and fluid-surface-active aggregates (Žutić \& Legović 1987, Žutić \& Tomaić 1988). All these surfaces have some degree of hydrophobicity, which should affect bacterial adhesion, even if the surface itself can be degraded by bacteria (Samuelsson \& Kirchman 1990, Baldi et al. 1999). The dropping mercury electrode (DME) (Adamson 1982), with its dynamic interface and pronounced hydrophobicity, can mimic the interfacial dynamics of natural fluid interfaces playing a role in the accumulation of bacteria and surface coagulation of oceanic organic matter (Johnson et al. 1986, 1994). 
Our recent work on adhesion and film formation by marine nanoflagellates as model cells (Žutić \& Tomaić 1988, Svetličić et al. 1997, Kovač et al. 1999) provides the experimental basis for studying the initial steps of bacterial attachment and film formation using electrochemistry. Cell adhesion is detected by the extent of its molecular contact with the electrode yielding a direct electrical signal. With the electrochemical sensor immersed in seawater, the adhesion forces can be fine tuned (Ivošević \& Žutić 1998) by changing the surface charge and tension, with all other properties of the system remaining unchanged. Hence, it should be possible, in principle, to study separately the interfacial interactions and properties responsible for adhesion and aggregation phenomena (Alldredge \& Jackson $1995)$ in the natural habitat.

We sought to answer the following questions: Are different strains of marine bacteria capable of immediate attachment to a treshly exposed surface? Is this attachment random and would it result in film formation on a time scale in which surface-active biopolymers adsorb at the interface? We have included in our study bacterial strains originally isolated as free-living or attached to particles, since they might represent different adaptive behaviors at interfaces.

\section{EXPERIMENTS}

Bacterial cultures. Several strains of marine bacteria were selected from a collection of isolates from the Southern California Bight: BF 2, BF 7 (Martinez et al. 1996) and S3 (Rehnstam et al. 1993). They are simple to grow in batch culture and can be easily separated from. the organic-rich growth medium. The orange pigmented BF 7 strain, isolated as free-living, belongs to the genus Cytophaga (L. B. Fandino unpubl.). It is a short-rod with filaments and it is not flagellated or motile under our growth conditions. BF 2, 0.8 to $1.4 \mu \mathrm{m}$ long, are motile, have long flagella and in a culture form large aggregates, which are easily disrupted by manual agitation. The yellow pigmented S3 is related to Cytophaga/Flavobacteria which occur in association with particles and have a surface-dependent gliding motility (DeLong et al. 1993). The cells were 1.4 to $4.0 \mu \mathrm{m}$ long and 0.4 to $0.6 \mu \mathrm{m}$ wide. In colonies they appear mucoid and in liquid medium exist as a mixture of single cells and stable aggregates (clumps of up to 500 cells). A fourth bacterium, Acinetobacter sp. RAG1 (ATCC 31012), was obtained by courtesy of Dr Franco Baldi.

The bacteria were grown as batch monocultures at $24^{\circ} \mathrm{C}$ under shaking. The growth medium was a commercial Marine Broth (DifCo), or ZoBell 2216E prepared with filtered seawater $(0.22 \mu \mathrm{m}$ Gelman filter).
The bacteria were counted by epifluorescence microscopy after staining with DAPI $(4,6$-diamidino-2-phenylindole; Porter \& Feig 1980).

The cultures were harvested after $24 \mathrm{~h}$ growth at the beginning of the stationary phase, by centrifugation $\left(5000 \times g_{i} 10 \mathrm{~min}\right)$, the supernatant was decanted, and the pellet was washed with filtered seawater $(0.2 \mu \mathrm{m})$. The pellets were resuspended in filtered seawater and centrifuged again. This procedure was repeated 3 times to remove traces of the growth medium. The cleanup was controlled polarographically by measuring the supernatant surface activity until it had decreased to that of seawater. The pellets were then resuspended in filtered seawater at cell densities of $5 \times 10^{9}$ to $5 \times 10^{10} \mathrm{ml}^{-1}$. The suspension was vortexed and aliquots were added directly to the electrochemical vessel containing $20 \mathrm{ml}$ of filtered seawater or organic-free $\mathrm{NaCl}$ solution.

Dextran solutions. Nonpolar dextrans (Serva; research grade) of average molecular weight 4000 (D-4), 70000 (D-70) and dextran sulphate sodium salt (Merck) of average molecular weight 500000 (D-500*) were used. The measurements were performed in an organic-free electrolyte solution containing $0.1 \mathrm{M}$ $\mathrm{NaCl}$ and $5 \mathrm{mM} \mathrm{NaHCO}$ to maintain the $\mathrm{pH}$ at 8 .

Electrochemical measurements. The measuring technique was a modification of a widely used polarographic technique for characterization of surfaceactive organic matter in aquatic environments (Nürnberg \& Valenta 1975, Hunter \& Liss 1981, Žutić et al. 1981, Cosović et al. 1985, Žutić \& Legović 1987. Marty et al. 1988, Zutić et al. 1990). It is based on measuring the suppression of the interfacial turbulence during oxygen reduction (Levich 1962, Barradas \& Kimmerle 1966. Sørensen 1978) in seawater caused by the adsorption and/or adhesion of its surface-active constituents. The adsorption of dissolved surfactants is manifested as a gradual decrease of the oxygen reduction current until it reaches the diffusion-controlled value. The adhesion of flexible organic particles (such as marine microaggregates, oil microdroplets and nanoplankton cells) causes a transient increase of interfacial turbulence resulting in the spike-shaped adhesion signals of individual particles (Žutić et al. 1993. 1998: Ivošević et al 1994; Ivnševió \& Žutić 1997. Kovač et al. 1999).

A fast DME with a drop life of $2 \mathrm{~s}$, a flow rate of $6 \mathrm{mg}$ $\mathrm{s}^{-1}$, and a maximum surface area of $4.7 \mathrm{~mm}^{2}$ (Fig. 1) was used. A polarographic Analyser PAR 174A was used and the current-time $(i-t)$ curves were recorded and stored with a Nicolet 3091 digital oscilloscope connected to a PC computer, or with a Gould 420 oscilloscope (Fig. 1).

The $i$ - $t$ curves were recorded at a constant potential. Most of the measurements were performed at $-400 \mathrm{mV}$ 


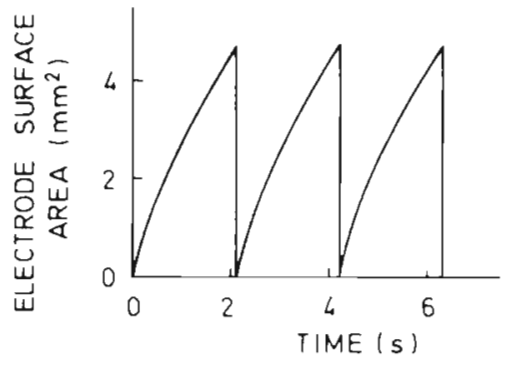

\section{ELECTROCHEMICAL SETUP}

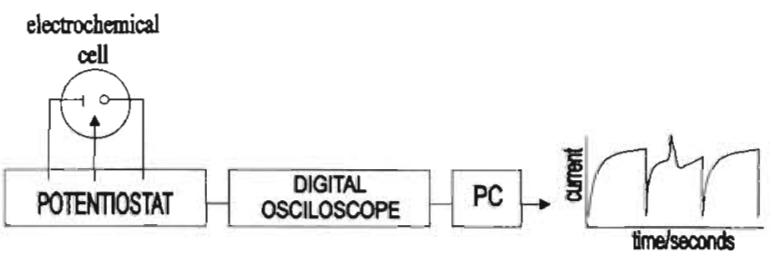

Fig. 1. Block scheme of the electrochemical measuring system; graph shows the dropping mercury electrode surface area as a function of time

versus an $\mathrm{Ag} / \mathrm{AgCl}$ reference electrode, where the mercury surface is positively charged (charge density = $+3.8 \mu \mathrm{C} \mathrm{cm}^{-2}$ ). ${ }^{1}$ A standard Metrohm vessel was used containing $20 \mathrm{ml}$ of dextran solutions, cell suspensions in seawater (diluted 1:5) or organic-free electrolyte (0.1 $\mathrm{M} \mathrm{NaCl}$ buffered with bicarbonate to $\mathrm{pH} 8$ ).

\footnotetext{
${ }^{1}$ By varying the applied potential between -0.1 and $-1.5 \mathrm{~V}$, the surface charge density of the electrode varies from +18 to $-17 \mu \mathrm{C} \mathrm{cm}^{-2}$, while the interfacial tension varies over a range of $100 \mathrm{m.J} \mathrm{m}^{-2}$ (Adamson 1982)
}

The samples were air saturated and maintained at $20^{\circ} \mathrm{C}$. The electrochemical cell was kept open to the air throughout the experiments. 'Organic-free' ultra-pure Milli-Q water was used for preparation of electrolyte solutions and for diluting seawater samples. Deep seawater collected from the Southern California Bight during a transit in the winter of $1995\left(117^{\circ} 40^{\prime} \mathrm{W}\right.$, $32^{\circ} 52^{\prime} \mathrm{N}$, depth $800 \mathrm{~m}$ ) was used in electrochemical measurements. It had a low adsorbable organic matter content (yielding a surface coverage of the electrode of $15 \%$ at the end of a drop life, at a potential of $-400 \mathrm{mV}$ ) and a low content of adhering particles $\left(<10^{3} \mathrm{l}^{-1}\right)$.

Model substance. Water soluble dextrans, which are flexible polymers of various molecular weight (4000 to $500000)$, were chosen as model substances. They are found as building blocks of cell walls and are active components of bacterial metabolism. The adsorption of dextran molecules is fast and controlled by mass transport from the solution. The dextrans are known for their specific adsorption at the mercury electrode in a range of positive and negative surface charges (Malfoy \& Reynaud 1988). Incidentally, the electrochemical adsorption effects of organic matter in a number of analyzed seawater samples resemble those recorded in diluted dextran solutions (Cosović \& Vojvodić 1982). Fig. 2A compares $i$ - $t$ curves for oxygen reduction in the presence of increasing concentrations of dextran sulphate D-500*. The extent of surface coverage of the mercury drop by dextran molecules is usually determined at the end of a drop life $(2 \mathrm{~s}$ in the present study). This mode of measurement is applicable up to $50 \mathrm{mg} \mathrm{l}^{-1}$ of D-500*. At higher concentrations $(65,80$, $100,500 \mathrm{mg} \mathrm{l}^{-1}$ ) the maximum surface coverage is reached earlier in the drop life. The experimentally
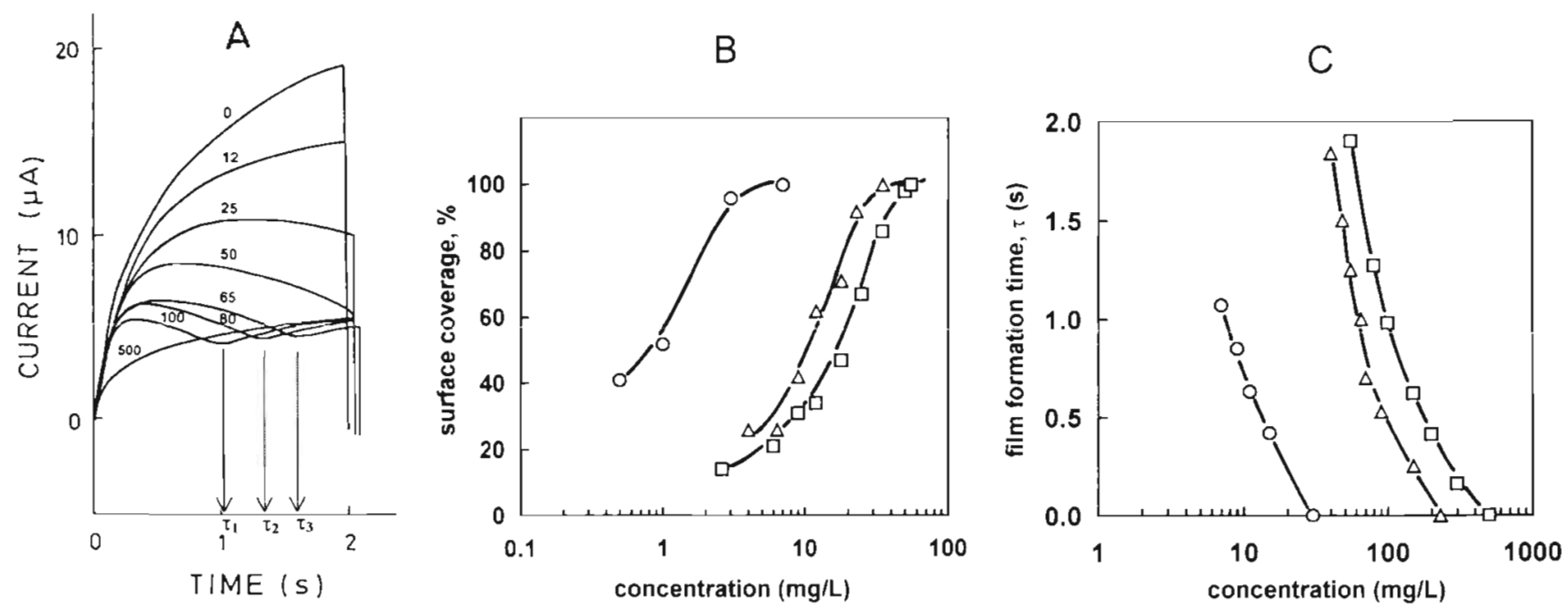

Fig. 2. Effect of dextran adsorption on the oxygen reduction current at the dropping mercury electrode in $0.1 \mathrm{M} \mathrm{NaCl}$ solution. (A) Overlaid $i-t$ (current-time) curves recorded in solutions with increasing D-500 concentrations (mg $\mathrm{l}^{-1}$ ). Curve 0 is an organicfree solution. (B) Surface coverage by dextran molecules and (C) film formation time, $\tau$, as functions of the dextran concentration: (O) D-4, ( $\Delta$ ) D-70, (口) D-500. 


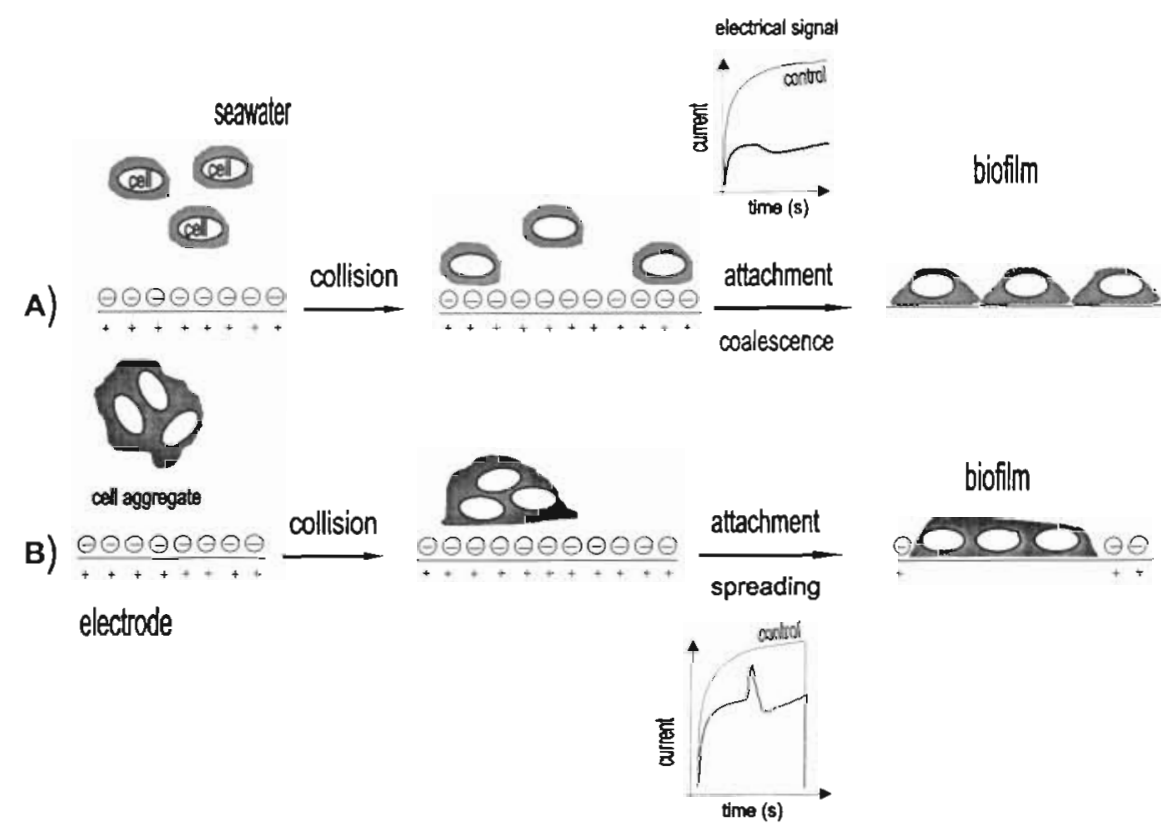

Fig. 3. Schematic representation of bacterial adhesion at a positively charged electrode and the resulting electrochemical signals: (A) adhesion of single bacterial cells and (B) adhesion of a cell aggregate

measurable time, $\tau$, needed to attain the maximum surface coverage characterizes the dynamics of film formation and is defined as the film formation time. $\tau$ decreases with increasing dextran concentration and drops to $\tau=0$ at high concentrations in solution $\left(500 \mathrm{mg} \mathrm{l}^{-1}\right)$. Analyses of $i$ - $t$ curves in terms of surface coverage measured at $t=2 \mathrm{~s}$ and $\tau$ could be performed in a broad concentration range of dextrans. Plots of surface coverage and $\tau$ versus concentration for $D$ 4. D-70 and D-500 are presented in Fig. $2 \mathrm{~B}$ and $\mathrm{C}$, respectively. The time needed to reach full monolayer coverage decreases exponentially with the increasing dextran concentration and for the same weight concentration depends strongly on the size of molecules. In the measured series, D-4 appears to be the most efficient in covering the electrode surface as a result of more efficient mass transport of smaller molecules.

The electrochemical technique should, in an analogous way, allow detection of bacterial adhesion by measuring surface coverage of the electrode immersed in a bacterial cell suspension. The adhesion mechanism of bacterial cells and establishment of a molecular contact with the electrode is illustrated by the simple schematic representation in Fig. 3A

\section{RESULTS AND DISCUSSION}

Prior to the electrochemical analysis, the morphology and aggregation state of bacteria (see Table 1) were examined by DAPI staining followed by epifluorescence microscopy, and the physiological activity was verified by oxygen consumption of bacterial culture. Oxygen consumption was monitored in dense cultures

by measuring the diffusion current of oxygen reduction at the DME (Svetličić et al. 1997).

A hydrophobic strain, Acinetobacter sp. (RAG-1), which is a common standard in hydrophobicity tests (Van der Mei et al. 1991) was used to study the role of hydrophobic interaction in biofilm formation. In RAG1 cultures and in the measured suspensions only single cells were detected microscopically; no aggregates were present. Cells were $0.7 \mu \mathrm{m}$ long and their electrophoretic mobility determined in a previous study was $3 \times 10^{-9} \mathrm{~m}^{2} \mathrm{~V}^{-1} \mathrm{~s}^{-1}$ (Baldi et al. 1999).

The $i$ - $t$ curves (Fig. 4 ) of suspensions of RAG- 1 cells, which were the only surface-active constituents in the system, are similar in appearance to those of dextran solutions (Fig. 2A). Each $i$ - $t$ curve corresponds to a bacterial suspension of a known cell density. Cell densities varied in a broad range from $1.6 \times 10^{5}$ to $8 \times 10^{8} \mathrm{ml}^{-1}$. The $i$ - $t$ curves are smooth and reproducible, implying a homogenous distribution of film-forming constituents

Table 1. Aggregation state of bacteria in measured suspensions in $0.1 \mathrm{M} \mathrm{NaCl}$ solutions and seawater as observed by epifluorescence microscopy after DAPI staining in aliquots of measured samples and related occurrence of attachment signals

\begin{tabular}{|lll|}
\hline Bacteria & Medium & Aggregation \\
\hline RAG-1 & $0.1 \mathrm{M} \mathrm{NaCl}$ & Unaggregated \\
BF 7 & Seawater & Mostly unaggregated \\
BF 2 & $0.1 \mathrm{M} \mathrm{NaCl}$ & Forms aggregates \\
& Seawater & Forms large aggregates \\
S3 & $0.6 \mathrm{M} \mathrm{NaCl}$ & Forms stable aggregates (clumps) \\
& Seawater & \\
\hline
\end{tabular}


Fig. 4. Effect of bacterial adhesion on the electrochemical current-time response. Overlaid amperometric curves of oxygen reduction in suspensions of increasing cell concentrations of strains RAG-1 and BF 7. RAG-1 cell densities (cells $\mathrm{ml}^{-1}$ ) in $0.1 \mathrm{M} \mathrm{NaCl}$ solution: (1) $1.6 \times 10^{5}$, (2) $1.3 \times 10^{6}$, (3) $2.6 \times 10^{6}$, (4) 2.6 $\times 10^{7},(5) 5.6 \times 10^{7},(6) 8.7 \times 10^{7}$ and (7) $8 \times 10^{8}$ BF 7 cell densities (cells $\mathrm{ml}^{-1}$ ) in seawater diluted 1:5: (1) $6 \times 10^{6}$, (2) $1.5 \times 10^{7}$, (3) $2.4 \times$ $10^{7}$, (4) $6 \times 10^{7}$, (5) $1.2 \times 10^{8}$, (6) $2 \times 10^{8}$, (7) 2.4 $\times 10^{8}$, (8) $3.6 \times 10^{8}$. Curves labelled 0 were recorded for organic-free electrolytes
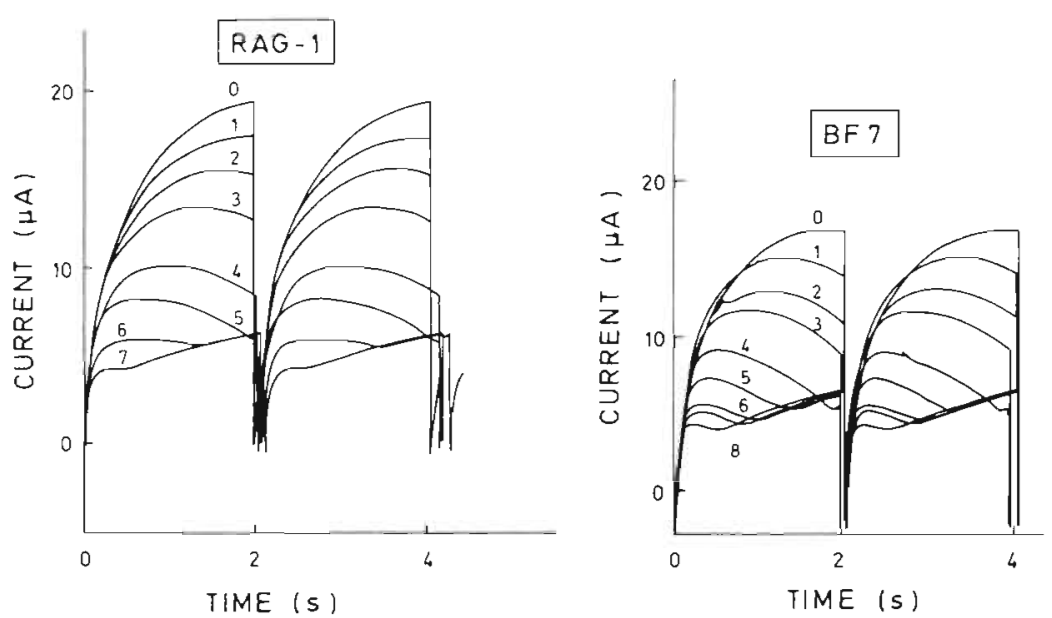

in the suspension. The oxygen reduction current of a bacterial suspension is gradually suppressed as the cell density in the suspension increases. The surface coverage of the electrode (Fig. 5A) increases with increasing cell densities in an analogous way to that of dextran solutions of increasing concentration (Fig. 2B). At a cell density of $4.4 \times 10^{7} \mathrm{ml}^{-1}$ the electrode is fully covered with a monolayer of surface active material after $2 \mathrm{~s}$. With further increase in cell density the time, $\tau$, needed to reach the full monolayer coverage by bacteria decreases exponentially (Fig. 5B).

The similarity with the behavior of dextran solutions implies that the rate-determining step in the initial film formation is the cell transport to the surface, while the cell adhesion is a faster step. However, the difference in the dynamics of film formation by RAG-1 cells and dextran became obvious at higher concentrations: (1) in concentrated dextran solutions, $\tau$ drops to zero as the dextran films are formed by a random adsorption of flexible molecules with a fast surface mobility; (2) in bacterial suspensions at high cell densities (Fig. 5B), $\tau$ reaches a constant value, $\tau_{\text {lim }}$, of $\sim 500 \mathrm{~ms}$. This difference identifies a rate-determining surface process in the bacterial film formation: a fast initial attachment of
RAG-1 cells is followed by a slower surface coalescence of the cell spreading zones (Fig. 3A) on the time scale of $500 \mathrm{~ms}$. A similar mechanism seems to govern the process of surface coagulation on air bubbles (Blanchard 1983, Johnson et al. 1986, 1994). In a separate study (Baldi et al, 1999) it was found, however, that surface coalescence was not the rate-limiting step in film formation by a marine strain with a polysaccharide capsule.

Having established the measurement procedure for bacterial film formation at a growing surface in RAG-1 suspensions we further explored the film formation by 3 different strains of marine bacteria isolated from the Southern California Bight. The bacterial strains differ in their presumed behavior in a natural habitat (attached vs free-living) and in their ability to form aggregates in suspensions of cells grown in monospecies cultures.

The adhesion effects were measured in cell suspensions of $10^{5}$ to $10^{9}$ cells $\mathrm{ml}^{-1}$. The $i$ - $t$ curves for BF 7 suspensions are shown in Fig. 4. In contrast to the monotonous and smooth signals in RAG-1 suspensions in pure electrolyte, they are characterized by the occasional appearance of small spikes. Such spikes indicate
Fig. 5. Dependence of (A) surface coverage and $(B)$ time of bacterial film formation on cell density of bacterial suspensions of strains RAG-1 (O) and BF 2 (口) in $0.1 \mathrm{M} \mathrm{NaCl}$ solutions, and of strains BF $7(\Delta), \mathrm{BF} 2(x)$ and S3 $(*)$ in diluted seawater
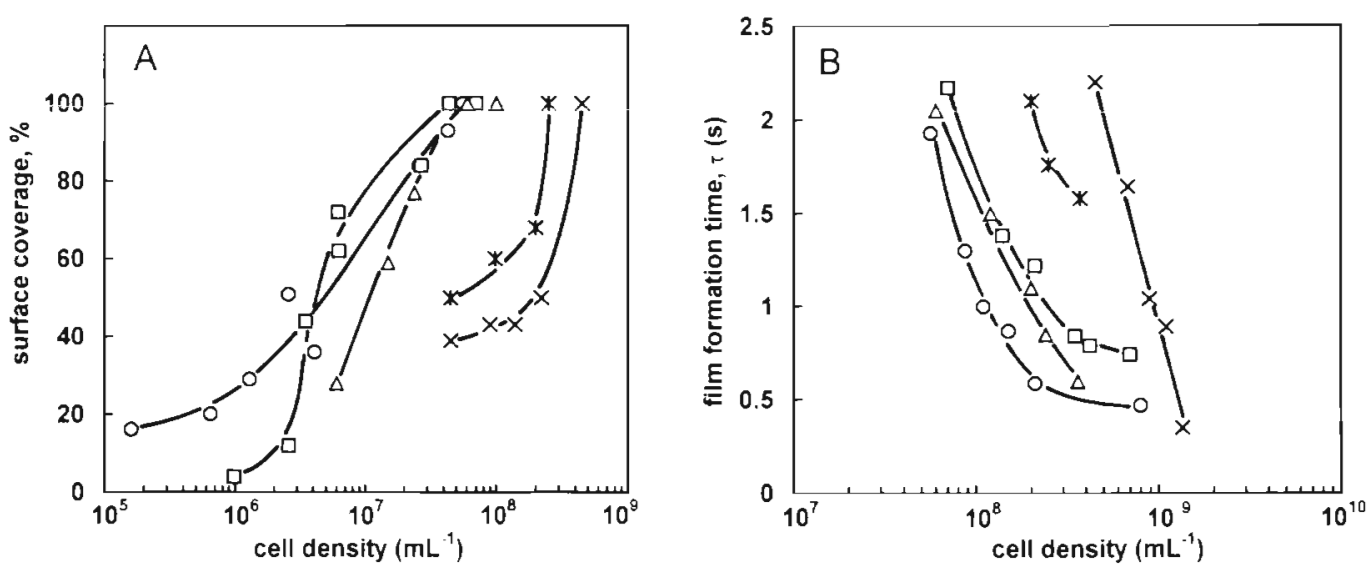


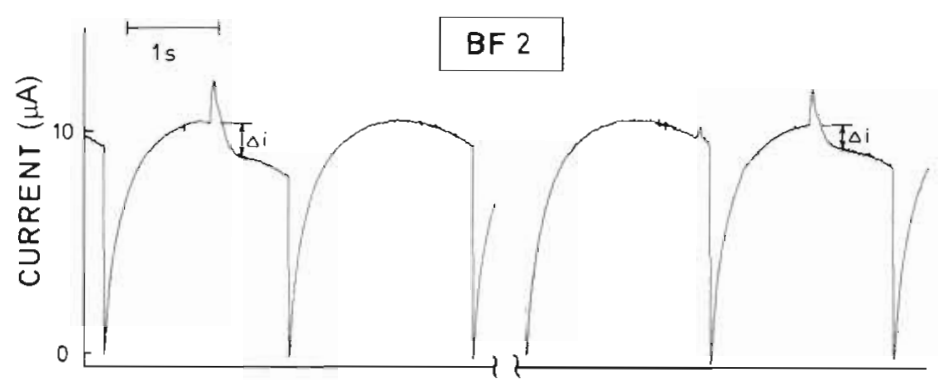

Fig. 6. Attachment signals of bacterial aggregates current-time curves of oxygen reduction in suspension of BF 2 cells at a density of $7 \times 10^{6} \mathrm{ml}^{-1}$ in diluted seawater with spike-shaped attachment signals. $\Delta i$ is the current suppression caused by adhesion of a cell

TIME aggregate

that adhesion of particles larger than a single bacterial cell have occurred (Svetličic et al. 1997), BF 7 suspensions were examined microscopically and indeed some aggregates were observed.

In order to register the electrical attachment signals of cell aggregates that appear randomly, it was necessary to record the $i$ - $t$ curves (Fig. 6) over a long time period (during 100 mercury drop lives). In a BF 2 suspension at $7.6 \times 10^{6}$ cells $\mathrm{ml}^{-1}$ the average frequency of attachment signals was 0.5 per drop life. This attachment frequency corresponds to an aggregate concentration of $5 \times 10^{3} \mathrm{ml}^{-1}$. The calibration curve was constructed using suspensions of Dunaliella tertiolecta, because these cells are large enough to yield a signal similar to that of the cell aggregates (Kovač et al. 1999). Analysis of the attachment signals of aggregated BF 2 cells is interesting for the understanding of the mechanism of bacterial film formation. The signals reflect the attachment of individual aggregates and their transformation to monolayer patches at the interface (Fig. 3B). The size of a patch can be determined experimentally from the relative decrease in the current after the attachment signal, $\Delta i / \Delta j_{\max }$ (Žutić et al. 1990). The largest aggregates were found to transform at the electrode within $200 \mathrm{~ms}$ into a film that occupies a surface area of $0.1 \mathrm{~mm}^{2}$. As the largest aggregates in the sample consisted on average of 500 bacterial cells, it follows that 1 BF 2 cell occupies an electrode surface area of $200 \mu \mathrm{m}^{2}$. This size of surface area exceeds by far the geometric area of the cell itself (cell length of approximately $1.4 \mu \mathrm{m}$ ). However, it is reasonable to anticipate that flexible polymers surrounding the cell spread over a surface area 161 in in diampter (e.g extensive mucus layers are seen around both attached and free-living marine bacteria, Heissenberger et al. 1996). The corresponding surface cell density, $5 \times 10^{5}$ cells $\mathrm{cm}^{-2}$, can be taken as a maximum cell density in the initial monolayer.

In Fig. 5A, B the dependence of surface coverage and $\tau$ on cell densities in suspension of strains of BF $7, B F 2$ and $\mathrm{S} 3$ are shown. The efficiency of the surface coverage of the electrode as well as the rate of the bacterial film formation in seawater increase in the sequence $B F$
$2<$ S $3<$ BF 7 . This sequence could be correlated with an increasing level of aggregation in cell suspensions: $\mathrm{BF} 7 \ll \mathrm{S} 3<\mathrm{BF} 2$ (Table 1 ).

The adhesion effects of BF 2 cells and their aggregates were compared in $0.1 \mathrm{M} \mathrm{NaCl}$ solutions and in seawater diluted to the same ionic strength. The frequency of appearance of adhesion signals (Fig. 6) is far more pronounced in diluted seawater than in pure $\mathrm{NaCl}$ solution of equal ionic strength and $\mathrm{pH}$. At the positively charged mercury surface, the adhesion signals of aggregates could be detected in both seawater and $\mathrm{NaCl}$ solutions. When a more negative potential is applied $(-800 \mathrm{mV}$ instead of $-400 \mathrm{mV})$ to change the surface charge of the electrode to negative values, the adhesion signals of aggregates appeared only in seawater. In $\mathrm{NaCl}$ solutions the adhesion signals of aggregates could not be detected. Such behavior was also found with cell aggregates of some other bacterial strains. The range of negative surface charge densities in which the adhesion of cell aggregates takes place might identify the prevalence of strong hydrophobic attraction over electrostatic repulsion (S3 strain, Svetličić et al. 1997).

The effect of aggregation on the rate of film formation was further investigated in experiments with BF 2 suspensions by varying the cell density in both diluted seawater and $0.1 \mathrm{M} \mathrm{NaCl}$ solution. The main difference between these 2 media is the presence of bivalent cations $\mathrm{Ca}^{2+}$ and $\mathrm{Mg}^{2+}$ in seawater. The remarkable difference in the rate of surface coverage (Fig. 5A) and film formation (Fig. 5B) in the 2 media is primarily caused by aggregation. Only in seawater do the aggregates of BF 2 and BF ? display attachment signals at the negatively charged electrode, indicating the role of bivalent cations in the aggregation and adhesion of the cell aggregates. The effect was even more pronounced with microaggregates from a natural habitat (Northern Adriatic seawater sampled prior to the onset of macroaggregation, Ivošević et al. 1998): the microaggregates appeared to adhere more strongly when the electrode surface was negatively charged. While the basis of this effect was not investigated in detail in this study, it is consistent with the findings of the important role the 
bivalent calcium cations of seawater play in bridging marine microgel particles leading to aggregation (Chin et al. 1998) and the role of calcium in the adhesion and fusion of bilayers carrying a net negative charge (Leckband et al. 1993). The presence of calcium cations was also found to enhance the cell-substrate interaction on metals other than mercury and on glass (Cooksey 1981). If $\mathrm{Ca}^{2+}$ bridging was indeed involved in the bacterial aggregation reported in this study, $\mathrm{Ca}^{2+}$-mediated bacterial aggregation would appear to be species specific. Furthermore, this might also be an important pathway that triggers bacteria-mediated aggregation of organic matter, e.g. the massive macroaggregation episodes in the eutrophic Northern Adriatic (Vollenweider \& Rinaldi 1995, Ivošević et al. 1998, Long et al. 1998).

In conclusion, we have characterized nonspecific interactions in the initial attachment and mechanism of film formation by marine bacteria at the model interface: seawater/dropping mercury electrode. Experimental evidence is presented that bacteria readily establish molecular contact with the substrate without the mediation of an organic conditioning film. The different strains of marine bacteria adhere directly at the freshly exposed free surfaces on a time scale of transport-controlled adsorption of biomolecules. The attachment of individual bacteria cells is fast and is transport controlled. After $2 \mathrm{~s}$ a detectable surface coverage $(>1 \%)$ is observed for cell densities of $2 \times 10^{5} \mathrm{ml}^{-1}$, while full coverage is attained at cell densities $>5 \times 10^{7} \mathrm{ml}^{-1}$. This was found to hold for bacterial isolates whether isolated as attached or as free-living from a natural habitat. If the results are translated to productive surface waters $\left(\sim 10^{6}\right.$ cells $\left.\mathrm{ml}^{-1}\right)$ a considerable surface coverage $(>10 \%)$ of freshly exposed surfaces by bacteria can be expected. This value is comparable to the surface coverage reported for raw seawater samples (Žutić et al. 1981, Cosović et al. 1985)

Cell aggregation causes a distinct difference in the dynamics of film formation compared to that of single cells. Aggregated bacteria exhibit specific attachment signals due to a rapid transformation of cell aggregates into a film when the attractive interaction of bacteria with the electrode surface exceeds the cell-cell interaction in the aggregate. The adhesion of bacteria is unlikely when the interfacial tension of the substrate decreases below a critical value. By extrapolation of the results obtained for the model to a natural habitat, it appears that bacterial attachment at freshly exposed fluid interfaces, such as seawater/air or air bubbles and oil droplets, will be dominated by nonspecific hydrophobic interactions and will be transport controlled. Since the cell-cell and the cell aggregate-substrate interactions were enhanced in seawater com- pared to those in pure $\mathrm{NaCl}$ solutions, our results raise the possibility of the importance of $\mathrm{Ca}^{2+}$ bridging in bacterial adhesion and bacterial aggregation in the marine environment.

Acknowledgements. We thank David C. Smith, Grieg F. Steward, Hans-Peter Grossart, Anna Obraztsova and Janice Y. Chung for help and discussions. We are grateful to Al Zirino for kindly providing PAR 174 and James Prechtl for sharing his oscilloscope for the experiments performed during the Fulbright fellowship of V.Z. at Scripps Institution of Oceanography. The research was supported in part by the Ministry of Science and Technology of the Republic of Croatia, Grant P-1508 and a travel grant to N.I., a Fulbright fellowship to V.Ž. and UNEP/IOC project No. 119820. F.A. and R.A.L. were supported by NSF grants to F.A.

\section{LITERATURE CITED}

Adamson AL (1982) Physical chemistry of surfaces. John Wiley, New York

Alldredge AL, Jackson GA (1995) Aggregation in marine systems. Deep-Sea Res II 42:1-273

Alldredge AL, Passow U, Logan BE (1993) The abundance and significance of a class of large transparent organic particles in the ocean. Deep-Sea Res 40:1131-1140

Baldi F, Ivošević N, Minnacci A, Pepi M, Fani R, Svetličić V, Zuutić V (1999) Adhesion of Acinetobacter venetianus to fuel oil droplets studied by in situ electrochemical and molecular probes. Appl Environ Microbiol 65:2041-2048

Barradas RG. Kimmerle F (1966) Effect of highly surfaceactive compounds on polarographic electrode processes. J Electroanal Chem 11:163-170

Blanchard DC (1983) The production, distribution and bacterial enrichment of the sea-salt aerosol. In: Liss PS, Slinn WGN (eds) Air-sea exchange of gases and particles. Reidel, Boston, p 407-454

Characklis WG, Marshall KC (1990) Biofilms. John Wiley, New York, p 202-203

Chin WC, Orellana MV, Verdugo P (1998) Spontaneous assembly of marine dissolved organic matter into polymer gels. Nature 391:568-569

Cooksey KE (1981) Requirement for calcium in adhesion of a fouling diatom to glass. Appl Environ Microbiol 41: 1378-1382

Cooksey KE, Wigglesworth-Cooksey B (1995) Adhesion of bacteria and diatoms to surfaces in the sea: a review. Aquat Microb Ecol 9:87-96

Cosović B, Vojvodić V (1982) The application of ac polarography to the determination of surface-active substances in seawater. Limnol Oceanogr 27:361-369

Ćosović B, Żutić V, Vojvodić V, Pleše T (1985) Determination of surfactant activity and anionic detergents in seawater and sea surface microlayer in the Mediterranean. Mar Chem 17:127-139

DeLong EF, Franks DG, Alldredge AL (1993) Phylogenetic diversity of aggregate-attached vs. free-living marine bacterial assemblages. Limnol Oceanogr 38:924-934

Heissenberger A, Leppard GG, Herndl GJ (1996) Relationship between the intracellular integrity and the morphology of the capsular envelope in attached and free-living marine bacteria. Appl Environ Microbiol 62:4521-4528

Hunter KA, Liss PS (1981) Polarographic measurement of surface-active material in natural waters. Water Res 15 : 203-215 
Ivošević N, Żutić V (1997) Polarography of marine particles: a model study. Croat Chem Acta 70:167-178

Ivošević N, Zutić V (1998) Spreading and detachment of organic droplets at an electrified interface. Langmuir 14: $231-234$

Ivošević N. Tomaić J, Žutić V (1994) Organic droplets at an electrified interface: critical potentials of wetting measured by polarography. Langmuir 10:2415-2418

Ivošević $N$, Svetličić $V$, Kovač $S$, Kraus $R$, Žutić $V$, Furić $K$ (1998) Bacterial and biophysical aspect of macroaggregation phenomena in the Northern Adriatic Sea. 1998 Ocean Sciences Meeting, San Diego, USA. Suppl to EOS, Trans Am Geophys Union 79:OS63 (Abstract)

Johnson BD, Azetsu-Scott K (1995) Adhesion force and a character of surfaces immersed in seawater. Limnol Oceanogr 40:802-808

Johnson BD, Zhou X, Wangersky PJ (1986) Surface coagulation in sea water. Neth J Sea Res 20:201-210

Johnson BD, Kranck K, Muschenheim DK (1994) Physicochemical factors in particle aggregation. In: Wotton RS (ed) The biology of particles in aquatic systems. CRC Press, Boca Raton, p 75-92

Kjelleberg S (1985) Mechanisms of bacterial adhesion at gasliquid interfaces. In: Savage DC, Fletcher M (eds) Bacterial adhesion: mechanisms and physiological significance. Plenum Press, New York, p 163-194

Kovač S, Svetličić V, Žutić V (1999) Molecular adsorption vs. cell adhesion at an electrified aqueous interface. Colloid Surf A 149:481-489

Leckband DE, Helm CA, Israelachvili J (1993) Role of calcium in the adheston and fusion of bilayers. Biochemistry 32: $1127-1140$

Levich VG (1962) Physicochemical hydrodynamics. PrenticeHall, Englewood Cliffs, p 413-429

Long RA, Azam F (1996) Abundant protein-containing particles in the sea. Aquat Microb Ecol 10:213-221

Long RA, Fandino LB, Steward GF, Del Negro P, Ramani P, Cataletto B, Welker C, Puddu A, Fonda S, Azam F (1998) Microbial response to mucilage in the guif of Trieste. 1998 Ocean Sciences Meeting, San Diego, USA. Suppl to EOS, Trans Am Geophys Union 79:OS63 (Abstract)

Malfoy B, Reynaud JA (1988) Alternating current polarographic investigation of polysaccharides in DNA. Anal Biochem 84:1-11

Martinez J, Smith DC, Steward GF, Azam F (1996) Variability in ectohydrolytic enzyme activities of pelagic marine bacteria and its significance for substrate processing in the sea. Aquat Microb Ecol 10:223-230

Marty JC, Żutić V. Precali R, Saliot A, Ćosović B, Smodlaka N, Cauwet $G$ (1988) Organic matter characterization in the northern Adriatic Sea with a special reference to the sea surface microlayer. Mar Chem 26:313-330

Muschenheim DK, Kepkay PE, Kranck K (1987) Microbial

Editorial responsibility: David Karl,

Honolulu, Hawaii, USA growth in turbulent suspension and its relation to marine aggregate formation. Neth J Sea Res 23:283-288

Nürnberg HW, Valenta P (1975) Polarography and voltammetry in marine chemistry. In: Goldberg ED (ed) The nature of sea-water. Dahlem Konferenzen, Berlin, p 87-136

Paul JH, Jeffrey WG (1985) The effect of surfactants on the attachment of marine and estuarine bacteria to surfaces. Can J Microbiol 31:224-228

Porter KG, Feig YS (1980) The use of DAPI for identifying and counting aquatic microflora. Limnol Oceanogr 25 943-948

Rehnstam AS, Backman S, Smith DC, Azam F, Hagstrom A (1993) Blooms of sequence-specific culturable bacteria in the sea. FEMS Microb Ecol 102:161-166

Samuelsson MO, Kirchman DL (1990) Degradation of adsorbed protein by attached bacteria in relationship to surface hydrophobicity. Appl Environ Microbiol 56: $3643-3648$

Sørensen TS (1978) Dynamics and instability of fluid interfaces. Lecture notes on physics, Vol 276. Springer Verlag, Berlin

Svetličić V, Ivošević N, Zuutić V (1997) Polarography of marine bacteria: a preliminary study. Croat Chem Acta 70: $141-150$

Van der Mei HC, Cowan MM, Busscher HJ (1991) Physicochemical and structural studies on Acinetobacter calcoaceticus RAG-1 and MR-481 - two standard strains in hydrophobicity tests. Curr Microbiol 23:337-341

Vaque D, Duarte CM, Marrase C (1990) Influence of algal population dynamics on phytoplankton colonization by bacteria: evidence from two diatom species. Mar Ecol Prog Ser 65:201-203

Vollenweider RA, Rinaldi A (1995) Marine mucilage. Sci Total Environ 165:1-230

Žutić $V$, Legović $T$ (1987) A film of organic matter at the freshwater/seawater interface of an estuary. Nature 328: $612-614$

Zutić V, Tomaić J (1988) On the formation of organic coatings on marine particles: interaction of organic matter at hydrous alumina/seawater. Mar Chem 23:51-67

Zuutić V, Ćosović B, Marčenko E, Bihari N, Kršinić F (1981) Surfactant production by marine phytoplankton. Mar Chem 10:505-520

Žutić V, Svetličić V, Tomaić J (1990) Dissolved and dispersed organic matter in natural waters. Progress by electroanalysis. Pure Appl Chem 62:2269-2276

Zutić V, Kovač S, Tomaić J, Svetličić V (1993) Heterocoalescence between dispersed organic microdroplets and a charged conductive interface. J Electroanal Chem 349: $173-186$

Žutić V, Ivošević N, Kovač S, Svetličić V (1998) An electrochemical approach to organic aggregation. Rapp Comm Int Mer Medit 35:310-311

Submitted: September 15, 1997; Accepted: October 29, 1998 Proofs received from author(s): June 7, 1999 